\title{
Research Material Development of Drama Appreciation Based on Local Wisdom on Student in Indonesian Literature and Language Education Program at Muhammadiyyah University of Makassar Indonesia
}

\author{
Anzar \\ Universitas Negeri Makassar, Jln. Bonto Langkasa, Kampus Gunung Sari, Makassar, South Sulawesi, Indonesia \\ Anshari \\ Universitas Negeri Makassar, Jln. Bonto Langkasa, Kampus Gunung Sari, Makassar, South Sulawesi, Indonesia \\ Juanda \\ Universitas Negeri Makassar, Jln. Bonto Langkasa, Kampus Gunung Sari, Makassar, South Sulawesi, Indonesia
}

\begin{abstract}
This research is a development research which aimed to produce teaching materials of the drama appreciation based on local wisdom on the students of the Indonesia literature and language education Faculty of Teacher and the Education Muhammadiyah University of Makassar which is valid, practical and effective. This is a Research and Development ( $R \& D)$ study by using 4-D model of development Thiagarajan through stages: (1) assessment or initial tracing of topics that will be constructed or reconstructed; (2) development of teaching materials products from the findings that has been achieved; (3) experimental material trial testers that have been developed at the research site and the product will be used (4) improvement of teaching materials in accordance with the findings in the preliminary situation in the field. The results of the research are (1) The teaching materials product of drama appreciation based on Bugis Makassar local wisdom is valid because the average validity of the validation result of the material expert $M=3.54$ is in the "Very Valid" class. (2) The product of study material of drama appreciation based on local wisdom of Bugis Makassar is considered practical because the average value obtained is $M=2$, it can be concluded that this value belongs to the class " fully implemented" (3) based on effectiveness criteria of teaching materials product based on local wisdom drama appreciation Bugis Makassar declared effective as data showed that the maximum completeness met and that $91.89 \%$ of students who received a score of 75 and above.
\end{abstract}

Index Terms - teaching material development, drama appreciation review, Bugis Makassar local wisdom

\section{INTRODUCTION}

Education as one of formal institutions is conducive to enhance creative potency within students. In order to create the expected surrounding, the process of learning and teaching must focus on students' learning activity as can as possible. They have to experience intellectual and emotional connection in the process of learning and teaching. One component of formal education in college, specifically in department of Indonesian language education and literatures, is teaching literature (including drama). By teaching drama with set of problems and emphasizing in literary activities, the creativity will be developed. Literary activity means as a creative process to enjoy and create literature actively. By that matter, there will be mental and spiritual connection towards the literary works. Accordingly, instructor (lecturer) has an important role for his position to create conducive environment in giving the students chance to do selfimprovement.

Lecturer's professionalism becomes as a standard of quality assurance in academic system. It has to be their cultural value to show the best work in implementing their duty and responsibility as a lecturer, whereas in academic environment enables positive connection between students to lecturer, lecturer to lecturer, and students to other students.

Drama as literary work is the inner of the authors that show personal freedom. Fully comprehend to personal freedom will encourage the readers (learners) to be creative. The drama also features characters with all the problems, characters, events, and conflicts. All of that is creatively overcome by the author. Someone who is involved in the drama will live up to new discoveries, new possibilities that affect the spirit of creativity. Through activities such as drama performances expression, conducive atmosphere actually created to foster the creativity. On the staging time activities, the learners interact with each other to discuss, talk, and work together for the staging preparation. 
Local wisdom can be internalized in education because it has advantages. These advantages according to Mulyani (in Taprianto, 2013) as follows: (1) local wisdom could become a learning tool for every human being to be a smart person, intelligent, and wise, (2) local wisdom has positive values to be transformed to Learners to form a positive personality. As Sayuti (in Taprianto, 2013) suggest that the culture and the local potential necessitates a strategic function for the formation of character and identity.

Based on that statement, it is deemed necessary to develop teaching material to improve the quality of learning drama. Teaching material in intent is material about drama appreciation based on the local wisdom of Bugis Makassar. The study of drama appreciation which is relevant in improving local wisdom of Bugis Makassar is the study that could foster the awareness of the contained values in teaching and learning process. By learning drama will eventually make the learners raise their awareness, cultivate their socialization, and know more about Makassar's cultural values.

Some important things that should be identified are how the design, validity, practicality, and effectiveness of teaching materials of drama appreciation based on local wisdom Bugis Makassar at the Muhammadiyah University of Makassar.

\section{A. Drama}

Literary works generally tell about reality in artistic form which its presence has special meaning for readers or devotees. The most complex of expressive language is arranged with full aesthetics becomes as the tool in bringing the reality into literary works.

Drama as a part of literary works cannot be separated from life. Through it, life's problems and humanity is proposed oftenly not far from public's social aspects in the relation between human to other humans. It also presents human behavior's aspects for its relation to human values. This can be seen in the matter of adore feeling, love, hatred, resentment, sincerity, purity, and so forth.

Drama is like a picture of the social life that is told through the show. Drama is a literary work that is structured to describe life and activity using various actions, dialogs, and character. The drama is full of acting and characters that amaze the audience. Drama is a work that designed for theater performances. Therefore, discussing the drama clearly will not be separated from the creative composition aspect (Endraswara, 2011, p.265).

Widyahening (2014, p.2-8) type of drama as follows, first, tragedy (drama sorrow or grief story) is a drama that depicts the sad story that is great and glorious. Second, the melodrama is a very sentimental story with the characters and stories that are breathtaking and moving. Third, comedy is light-hearted dramas, has a hilarious dialogue that is sarcastic and usually ends with happiness. Fourth, slapstick also called jokes.

The term of drama contains two interpretations. The first is text play or repertoire and the second is theatre or performance. Semi (1993, p.157) confirmed that drama in general has two aspects that is story aspect as the part of literature and staging aspect involving the art of play or the art of theatre. Speaking of drama, then we are dealt with two possibilities, specifically script drama and stage drama. Both of them are based on script drama. Therefore, the discussion regarding script drama becomes as the basic of drama study.

\section{B. Drama Teaching}

The relationship between the language elements in a literary work demands a special ability of the reader to find the meaning or message that contained in the literary work. These skills include conducting preliminary analyses of texts that, according to Nurgiyantoro (2002, p.165), are intended to find the meaning of each constituent element, as well as finding for relationships between elements that can form the overall meaning of the text. This requires a systematic exercise and repetitive that will be more effective if it is designed in a systematic literature learning process. The process referred to by Teeuw (1991) should be able to familiarize learners with existing conventions. Only through a process that enables learners' understanding of the conventions, students will be able to develop their sensitivity while facilitating their whole interpretation.

A literary work is essentially a collection of words that should be analyzed for its meaning. In literary learning, the level of understanding is also determined by the selection of texts to be read. Principally because the text is read should have a relationship with the reader capacity. This means that the success of learning to improve understanding is also determined by the ability of teachers (lecturers) to choose the text that will be used as teaching materials.

There are some things to note in the selection of materials in the use of teaching materials for drama, that is 1). Consider the objectives to be achieved, whether orienting the mastery as much as possible (literature caught) or appreciation ability even with the relatively little (literature taught) material; 2). Source material, where it is necessary to consider whether the drama as a whole or a fragment of a scene or dialogue quotations for specific purposes such as enrichment appearance, conversation, and oral skills. In this case, the drama learning integrated with other learning; and 3). Considering the aesthetics of drama and types of drama (Endraswara, 2005, p.195-196).

In literature teaching, the level of comprehension is defined by text selection to be read. This is because of text principle that reading material must relate to reader's capability. It means that the goal of learning to improve comprehension is also considered by teacher's ability in selecting text to be used for learning material. It has to meet students' age and their interest. Moody (1971) explained several criteria of text selection of literary works which prioritises students' age, language, psychology, and theme's background. For far explanation in language aspect, it needs to consider levels of language difficulties of text with the students' capability. It can be seen in the use of 
grammar and variety of vocabularies used. As with psychology aspect, it is related to students' interest and enthusiasm towards text. The last aspect, theme's background, refers to theme selection which is not too unfamiliar or already known by students.

\section{Local Wisdom}

Generally, local culture or regional culture is considered as the expanding culture in a region with the elements of ethnic group's culture who inhabit the area. The implementation of sustainable development along technology advance leads people to abandon the importance of tradition or public culture in managing environment which is also oftenly regarded as old-fashioned in this era that makes this development planning far from the public.

The importance of local wisdom in wide education becomes an effort to maintain national endurance as a proud nation. The culture of archipelago with its pluralism and dynamism is a source of eternal local wisdom that makes it as unavoidable living reality.

The term local wisdom consists of two words, namely wisdom and local. Thus, local wisdom (local wisdom) can be understood as ideas and knowledge that are wise, full of wisdom, good value, and virtuous owned, guided and implemented by its members (Sibarani, 2012, p.112).

In local wisdom, also contained local cultural wisdom. Local wisdom itself is the local knowledge that has been so integrated with the system of beliefs, norms, and culture and expressed in the traditions and myths espoused in the long term. As one form of human behavior, local wisdom is not a static thing but changes over time, depending on the order and social-cultural bonds that exist in society.

Local wisdom can be understood as a human effort by using its sense of cognition to act and behave on things, objects, or events that occur in a certain space (Ridwan, 2007).

Etymologically, wisdom means a person's ability to use his or her mind to respond to events, objects or situations. While local shows the interaction space in which the event or situation occurs. Thus substantially, local wisdom is the values and norms that apply in a society that is believed to be true and become a reference in acting and behaving every day. In other words, local wisdom is the ability to address and empower the potential values of the noble local culture. Behavior that is general and prevailing in society extensively, hereditary, will evolve into firmly held values, hereinafter referred to as culture. Local wisdom is defined as a truth that has been traditionally or steadily in an area (Gobyah, 2003).

Substantially, local wisdom is the prevailing values in a society. The values are believed to be true and become a reference in the daily behavior of the local community. Therefore, it is reasonable to say that local wisdom is an entity that really determines the human dignity of the community.

In society, local wisdom can be found in the song, proverb, Sasanti, advice, slogan, and ancient scriptures inherent in everyday behavior. Local wisdom is usually reflected in long-standing community habits. The sustainability of local wisdom will be reflected in the prevailing values within certain community groups. These values become the hold of certain groups of people who would normally become an integral part of life that can be observed through their daily attitudes and behaviors.

\section{The Values of Bugis Makassar Culture}

Community approval of a concept, belief, idea, and views that result in attitude and will, that is the cultural system that guides their behavior or becomes characteristic of a person. In general, culture is none other than the ways of humans as social beings who used to manage life and its environment. The knowledge that gained from the culture becomes the foundation framework to encourage the manifestation of behavior. The behavior that formed together in social institutions will finally materialize the work of material and non-material (Hamid, 2006).

The values elements of the culture are closely related to the culture norms elements. Culture concept that is expressed by Rapoport in Beddu (2014), in relation to the establishment of the built environment that, to see the cultural values specifically, beside the lifestyle of the people, also look at the image, pattern, and sense that is understood by the society which then can be materialized in the form of certain agreed norms or rules.

Sikki (1991, p.31) the role of Makassar literature that recorded in lontarak is a reflection of the mindset and behavior of the people of Makassar since centuries ago. Although this literature is just one aspect of Makassar cultures, this literature is able to provide a general and intact description of the character, personality, and all aspects of life as well as living within the scope of the culture. It can be read in various lontarak such as rappang, pappasang, ulu kana, and kelong.

Abdulah (1985, p.17) proposes the Bugis Makassar community value system in the concept of siri, pace and pangadereng supported by elements that build human moral life, namely (1) ade or custom; (2) rapang or legislation; (3) wari or rule of difference of rank of nationality; (4) bicara or speech and speak; (5) sara.

Siri ', for the Bugis-Makassar people is himself, is the man himself, something very fundamental in their life order. Siri 'is the soul of Bugis-Makassar man. The concept of tau tena tokdok pulina among the people of Makassar, such a person who is not worthy of being mandated or trusted (tau tena nakatappak or takkulle nitakgalak ulu kananna); untrusted, similar with Makassar expression punna tau kananna nitagalak, which means man's world held. Therefore, Makassar people who do not have tokdok puli culture means people who are considered tau siri'na 'people who do not have shame'. In the concept of Makassar culture that such a person is not a perfect man (Sikki, 1991, p.62). 


\section{Methodology}

\section{A. Type of Research}

This is a Research and Development research ( $R \& D$ ) used 4-D Thiagarajan development model, in order to develop the teaching materials of drama appreciation based on Bugis-Makassar local wisdom. The products developed based on findings, conduct field trials in accordance with the setting on which the product is used, and revise field tests (Setyosari, 2010, p.194).

\section{B. Research Design}

The process of Research and Development (R \& D) takes place cyclically, through the following stages: (1) define or trace the topics that will be constructed or reconstructed; (2) the design of teaching materials from the findings that have been achieved; (3) the development of teaching materials that have been developed at the research site and the product that will be used (4) distribution is the stage of the use of teaching materials that have been developed.

\section{Research Instruments}

The instruments in this study were: (1) validation of teaching materials, (2) observation sheets, (3) student response questionnaires, and (4) student's mastery test on the subject matter.

\section{Technique of Data Analysis}

The data obtained by using the instruments then analyzed quantitatively to answer the question "does the learning device meet the valid, practical and effective? The data obtained from the validation results of experts and practitioners are analyzed to answer the question "whether the material is valid or not?" While the data obtained by conducting trials analyzed to answer the question "whether the material is practical and effective or not?"

\section{The RESUlt OF THE RESEARCH}

In this section, the researchers describe the results of the research in the design form and the analysis results of validity, practicality, and effectiveness of teaching materials appreciation of drama based on Bugis Makassar local wisdom Bugis Makassar at the University of Muhammadiyah Makassar. The results of the research data analysis are described as follows.

1. The description of data analysis results of the teaching materials prevalence of products and study of drama appreciation based on local wisdom of Bugis Makassar

The data's validity of teaching materials product of drama appreciation based on Bugis Makassar local wisdom is obtained from validation result of the material expert. Validation is done used questionnaire which contained various criteria of validity product of teaching materials of drama appreciation based on Bugis Makassar local wisdom.

The result of the data analysis of material expert validation shows that the average value is $\mathrm{M}=3.54$, it can be concluded that this value belongs to the category of "Very Valid". So, reviewed from the whole aspect, the learning materials product of drama appreciation based on the local wisdom of Bugis Makassar is stated to meet the criteria of validity.

2. The result of data analysis description of the practic 3 teaching material products study drama based on appreciation of Bugis Makassar local wisdom

The practical data of teaching materials product of drama appreciation based on the local wisdom of Bugis Makassar obtained from observation of the general teaching material from two observers.

Generally, based on the data analysis result of the implementation of teaching materials product of drama appreciation based on Bugis Makassar local wisdom, the total average value obtained is $\mathrm{M}=2$, it can be concluded that this value belongs to the category "fully implemented". So, reviewed from the whole aspect, the learning materials of the drama appreciation based on Bugis Makassar local wisdom is stated to meet the criteria of implementation.

3. The results of data analysis description of the effectiveness of teaching materials product assessment of drama based on Bugis Makassar local wisdom

The data of the effectiveness of teaching materials product on drama appreciation based on Bugis Makassar local wisdom aimed at the achievement of individual and classical learning outcomes. A success student in learning is if she/he gets a minimum score of 75 . The Learning is a success in a classical manner if at least $85 \%$ of students achieve a minimum score of 75 .

Generally, the achievement of individual and classical learning results indicates that the number of students who complete the study or who achieve the completeness of individuals is students who scored 75 to 96 as many as 34 people from 37 students or about $91.89 \%$. So the number of students who have not completed, namely students who get a score of $0-74$, as many as 3 people from 37 students or about $8.10 \%$. This data shows that the maximum completeness has fulfilled that is $91.89 \%$ of students who scored 75 and above. Based on the criteria the effectiveness of teaching materials product, the appreciation of dramas based on Bugis Makassar local wisdom can be concluded that in the experiment, learning tools have been effective because they meet 4 indicators of effectiveness including indicators of learning outcomes. 
The results obtained above indicated that in the conducted experiments, the learning material product of drama appreciation based on Bugis Makassar local wisdom has met the criteria of validity, practicality, and effectiveness.

\section{DISCUSSION}

The product produced in this research is the learning materials of drama appreciation based on Bugis Makassar local wisdom that has fulfilled the criteria of validity, practicality, and effectiveness through the stages: (1) define or trace the topics that will be constructed or reconstructed; (2) the design of teaching materials from the findings that have been achieved; (3) the development of teaching materials that have been developed at the research site and the product that will be used (4) distribution is the stage of the use of teaching materials that have been developed.

This section discusses the results of this research that include the results of data analysis of validity, practicality, and effectiveness of teaching materials product of drama appreciation based on Bugis Makassar local wisdom which has been developed. The discussion is presented as follows,

1. The validity of teaching materials product of drama appreciation based on local wisdom of Bugis Makassar

The result of data analysis of material expert validation shows that the average value is $\mathrm{M}=3.54$, it can be concluded that this value belongs to the category of "Very Valid". So, reviewed from the whole aspect, the product of learning materials of drama appreciation based on Bugis Makassar local wisdom is stated to meet the criteria of validity.

The assessment results from the experts and practicioners in education field showed that the product of drama appreciation's review as learning material based on Buginese Makassar local wisdom whereas the problems had been reviewed from the whole aspects was stated as valid, although there were several suggestions to be considered for the completeness of the developing tools.

2. Practicality of teaching materials product of drama appreciation based on local wisdom of Bugis Makassar

Based on the results of data analysis in the implementation of teaching materials product of drama appreciation based on Bugis Makassar local wisdom, the total average value obtained is $\mathbf{M}=2$, it can be concluded that this value belongs to the category "fully implemented" ( ). So, reviewed from the whole aspect, the product of learning materials of drama appreciation based on Bugis Makassar local wisdom is stated to meet the criteria of implementation.

3. The effectiveness of teaching materials product of drama appreciation based on Bugis Makassar local wisdom

The achievement of individual and classical learning results indicates that the number of students who complete the study or who achieve the completeness of individuals is students who scored 75 to 96 as many as 34 people from 37 students or about $91.89 \%$. So the number of students who have not completed, namely students who get a score of 0 74 , as many as 3 people from 37 students or about $8.10 \%$. This data shows that the maximum completeness has fulfilled that is $91.89 \%$ of students who scored 75 and above. Based on the criteria the effectiveness of teaching materials product, the appreciation of dramas based on Bugis Makassar local wisdom can be concluded that in the experiment, learning tools have been effective because they meet 4 indicators of effectiveness including indicators of learning outcomes.

\section{CONCLUSION}

Based on data analysis and discussion of research result of research development materials of drama appreciation based on Bugis Makassar local wisdom, it can be concluded the result of this research, that is:

The teaching materials product of drama appreciation based on Bugis Makassar local wisdom is stated very validly because the average validity of the validation result of the material expert is $M=3.54$ which is in the category of "Very Valid".

The learning materials product of drama appreciation based on Bugis Makassar local wisdom is practicable because the average value obtained is $M=2$, it can be concluded that the value belongs to the category "fully implemented".

Based on the criteria the effectiveness of teaching materials product, the study of wisdom appreciation based on Bugis Makassar local wisdom is declared effective because the data shows that the maximum completeness that has fulfilled is $91.89 \%$ of students who get score 75 and above.

\section{REFERENCES}

[1] Abdullah, H. (1985). Manusia Bugis-Makassar. Jakarta: Inti Idayu Press.

[2] Beddu, Syarif. (2014). Eksplorasi Kearifan Budaya Lokal sebagai Landasan Perumusan Tatanan Perumahan dan Pemukiman Masyarakat Makassar. Jurnal Temu Ilmiah IPLBI (2014). http://temuilmiah.iplbi.or.id/ (accesed 20 Januari 2016).

[3] Endraswara, Suwardi. (2011). Metodologi Penelitian Sastra: Epistemologi, Model, Teori, dan Aplikasi. Yogyakarta: Caps.

[4] Endraswara, Suwardi. (2005). Metode dan Teori Pengajaran Sastra. Yogyakarta: Buana Pustaka.

[5] Gobyah, I.K. (2003). Berpijak pada Kearifan Lokal. http://www.balipos.co.id (accesed 17 Januari 2016)

[6] Hamid, Abu. (2006). Semangat Islam dalam Kebudayaan Orang Bugis-Makassar. Jurnal Jafray. (4), p.1 http://ojs.sttjaffray.ac.id. (accesed 20 Januari 2016).

[7] Nurgiyantoro, Burhan. (2002). Teori Pengkajian Fiksi. Yogyakarta: Gadjah Mada University Press.

[8] Ridwan, Nurman Ali. (2007). Landasan Keilmuan Kearifan Lokal. Penelitian. Purwokerto: STAIN Purwokerto.

[9] Setyosari, Punaji. (2010). Metode Penelitian Pendidikan dan Pengembangan. Jakarta: Prenada Media group. 
[10] Sibarani, Robert. (2012). Kearifan Lokal, Hakikat, Peran, dan Metode Tradisi Lisan. Jakarta. Asosiasi Tradisi Lisan.

[11] Sikki, Muhammad. (1991). Nilai-nilai Budaya dalam Susastra Daerah Sulawesi Selatan. Ujung Pandang. Balai Penelitian Bahasa.

[12] Taprianto, Toni. (2013). Pengembangan Materi Pembelajaran Menyimak Informasi Bermuatan Kearifan Lokal pada Siswa SMP. [online]. Tersedia: http://lib.unnes.ac.id. (accesed 9 Januari 2016).

[13] Teeuw, Andrea. (1991). Membaca dan Menilai Sastra. Jakarta: Gramedia

[14] Widyahening. (2012). Kajian Drama Teori dan Implementasi. Surakarta: Cakrawala Media.

Anzar, born October 24, 1984 in Pangkajene. The author was the fourth of four children of the couple, Drs. Nurdin, M and Dg Nursiah. Dg. Puji (RIP). He completed elementary school in the SD Inpres Baraya 2 Makassar (1996); the first secondary education at JUNIOR HIGH SCHOOL 8 Makassar (1999); upper secondary education in SMA Negeri 1 Pangkajene (2003); education level of S-1 (Bachelor) in the Makassar State University at the Faculty of engineering, Department of Automotive, in 2005 the author transfers to the Faculty of language and literature, Department of language and literature of Indonesia and the region, Indonesian Language education courses (2010) ; education level S-2 (master's degree) in PPs UNM (2012). Writer continuing education level S3 (Doctorate) in graduate program UNM in 2013 - now.

Anshari, born in Enrekang, South Sulawesi, 29 April. He completed Elementary School in SD Negeri Maccini Kompleks II Ujung Pandang (1972); the secondary education in JUNIOR HIGH SCHOOL 10 Ujung Pandang (1980); upper secondary education in Senior High School 4 Ujung Pandang (1983); education level of S-1 (Bachelor) in IKIP Ujung Pandang (1988); education level S2 (master's degree) in graduate program HASANUDDIN UNIVERSITY in Makassar (1999); and education level S-3 (Doctorate) at the State University of graduate program Malang (2007). He was noted as a lecturer since 1989 remains on the Faculty of language and literature, Department of language and literature of Indonesia and the region, the State University of Makassar.

Juanda, born on 10 March 1968 in Salobulo, Wajo. He completed elementary School in SDN No. 195 Tanete (1980); the secondary education in SMP NEGERI Keera, Wajo (1983); upper secondary education in SMA NEGERI 22 Sengkang (1986); education level of S-1 (Bachelor) at HASANUDDIN UNIVERSITY (1990); education level S-2 (master's degree) in graduate program HASANUDDIN UNIVERSITY (1994); and education level S-3 (Doctorate) in the graduate program State University Jakarta (2010). He was noted as a lecturer since 2001 at the Faculty of language and literature, Department of language and literature, University of Indonesia and the region, Universitas Negeri Makassar. 